\title{
ИНФОРМАЦИОННО-КОММУНИКАЦИОННЫЕ ПРОЦЕССЫ
}

www.volsu.ru

DOI: https://doi.org/10.15688/jvolsu4.2020.3.16

UDC 94(41/99), 327.83+37

Submitted: 28.08.2019

LBC 66.4(2Poc), 0

Accepted: 13.12 .2019

\section{PROMOTING THE RUSSIAN LANGUAGE AND CULTURE IN SPAIN AS A SOFT POWER TOOL OF THE RUSSIAN FEDERATION ${ }^{1}$}

\author{
Viktoriia V. Kuznetsova \\ Peoples' Friendship University of Russia, Moscow, Russian Federation
}

\begin{abstract}
Introduction. This work inspects the activities of Russian institutions (government agencies, foundations, public associations and educational organizations) as instruments of soft power in the field of the dissemination of the Russian language and culture in Spain. The pre-requisites of establishing the language strategy as a foreign policy instrument, the main forms and sphere of activities in promoting and supporting the Russian language in Spain are analyzed in this article. Methods. The comparative historical method is used to substantiate the aspects of the formation and development of the language policy program of the Russian Federation in Spain and other European countries in the historical retrospective. The systematic approach is used to formulate a holistic view of the policy of promoting the Russian language and culture in Spain as an instrument of soft power. Also, the institutional and neo-institutional approaches are used to identify formal and informal institutions of soft power in the field of popularization of the Russian language and culture in Spain. Analysis. As a result of analyzing the problem, the legal foundations and institutional foundations of the activities of the Russian Federation to popularize the Russian language and culture in Spain have been studied. The main directions and results of the soft power policy in the field of popularizing the Russian language and culture in Spain and their role in creating a positive image of Russia in Spain have also been identified. Results. The study shows that in recent years, thanks to the soft power policy, the Russian Federation has managed to maintain and, in some positions, expand its presence in Spain in the humanitarian and information space.

Key words: soft power, Russian foreign policy, language policy, cultural policy, "Russian world", Spain, Russia.

Citation. Kuznetsova V.V. Promoting the Russian Language and Culture in Spain as a Soft Power Tool of the Russian Federation. Vestnik Volgogradskogo gosudarstvennogo universiteta. Seriya 4. Istoriya. Regionovedenie. Mezhdunarodnye otnosheniya [Science Journal of Volgograd State University. History. Area Studies. International Relations], 2020, vol. 25, no. 3, pp. 180-191. DOI: https://doi.org/10.15688/jvolsu4.2020.3.16
\end{abstract}

УДК 94(41/99), 327.83+37

Дата поступления статьи: 28.08.2019

ББК 66.4(2Poc), 0

Дата принятия статьи: 13.12.2019

\section{ПРОДВИЖЕНИЕ РУССКОГО ЯЗЫКА И КУЛЬТУРЫ В ИСПАНИИ КАК ИНСТРУМЕНТ «МЯГКОЙ СИЛЫ» РОССИЙСКОЙ ФЕДЕРАЦИИ ${ }^{1}$}

\author{
Виктория Владимировна Кузнецова \\ Российский университет дружбы народов, г. Москва, Российская Федерация
}

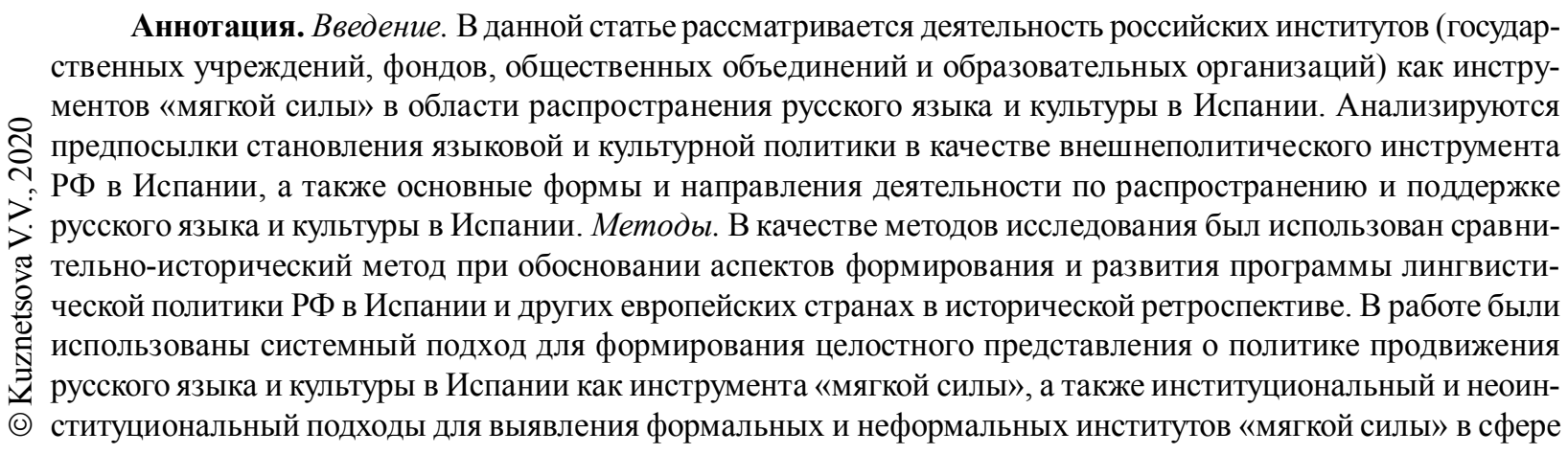


популяризации русского языка и культуры в Испании. Анализ. В результате анализа проблемы были изучены нормативно-правовая база и институциональные основы деятельности Российской Федерации по популяризации русского языка и культуры в Испании. Также были определены основные направления и результаты политики «мягкой силы» в области популяризации русского языка и культуры в Испании и их роль в формировании положительного имиджа России в Испании. Результаты. Исследование показало, что в последние годы благодаря политике «мягкой силы» Российской Федерации удалось сохранить, а по некоторым позициям расширить свое присутствие в Испании в гуманитарном и информационном пространстве.

Ключевые слова: «мягкая сила», российская внешняя политика, лингвистическая политика, культурная политика, «Русский мир», Испания, Россия.

Цитирование. Кузнецова В. В. Продвижение русского языка и культуры в Испании как инструмент «мягкой силы» Российской Федерации // Вестник Волгоградского государственного университета. Серия 4, История. Регионоведение. Международные отношения. - 2020. - Т. 25, № 3. - С. 180-191. - (На англ. яз.) - DOI: https://doi.org/10.15688/jvolsu4.2020.3.16

Introduction. Due to the increased pace of globalization and internationalization, many countries have shifted from the military and economic sphere to culture and education. Currently, there is a focus on "soft power" instruments in foreign state policies. In regard to this concept, countries promote and defend their national interests to create a positive image on the global stage. Currently, cultural diplomacy which includes soft power policy plays the most important role for Russia.

Secondly, Russia and Spain never went to war against each other. The dialogue between the two countries is based on strong cultural relations with a long historical tradition which serve as an important pre-requisite for developing the Russian-Spanish co-operation in the sphere of education.

Despite the hardship in the relations between Russia and the EU countries, the Russian culture and language (especially after the 2018 FIFA World Cup) still attract Spain.

Finally, this topic is timely due to the fact that the promotion of the Russian language in Spain is poorly explored despite the emphasis on bilateral political, economic and cultural relations in Russian and Spanish literature.

Methods. At present, one of the most important goals of any state is to strengthen its international position and authority, as well as to provide favorable foreign policy conditions for solving domestic political problems.

The cusp of the $20^{\text {th }}$ and $21^{\text {st }}$ centuries witnessed active discussion and the use of soft power in the sphere of international clout and defense of national interests [46, p. 57]. Nevertheless, this concept has appeared in the domestic and foreign scientific community long ago. According to O. Krasina, the soft power phenomenon was mentioned first in Ancient Chinese and Greek philosophy by Laozi, Confucius, Plato and Aristotle. Later thoughts on the efficiency of non-violent methods were mentioned in the works of medieval and early modern thinkers such as Augustine of Hippo or Blaise Pascal. Krasina also considers H. Grotius, I. Kant, M. L. King and M. Gandhi as the predecessors of the concept of soft power [25].

Nevertheless, Joseph Nye, professor of Harvard University, should be considered as the rightful author of the soft power concept. According to the scholar's work, the main method of the state to reach the desired foreign policy goals is making its culture, ideology, domestic and foreign policy more attractive [35, p. 16].

The cultural and spiritual potential forms an important part of any state, so both global and regional actors of international relations actively use promotion of cultural experience abroad as a soft power instrument [53, p. 24].

In Russia, the embrace of soft power has started since 2000 s when V. Putin was elected as president [24, p. 97]. Due to the important role of this concept in strengthening the international image of the country, the president made it one of the key instruments of the Russian foreign policy.

The target of the research is Russia's soft power policy in Spain. The subject of the research is the main spheres of promoting and supporting the Russian language and culture in Spain on the new stage of bilateral relations (1990s - 2000s). The aim of this work is to create a comprehensive picture on the formation and implementation of the Russian language policy in Spain as a soft 
power instrument and to determine the role and the results of this policy in shaping the cultural image of Russia in Spain.

The comparative-historical method is used to justify the aspects of the formation and development of the language policy program of the Russian Federation in Spain and other European countries in the historical retrospective. The comprehensive approach is applied for studying the role and significance of promoting Russian in Spain as a soft power instrument in the contemporary foreign policy of Russia. The institutional approach reveals the features of the functioning of individual soft power institutions in the field of the Russian language policy, which is represented by state institutions, professional organizations, news agencies, and non-profit structures. The non-institutional approach allows us to determine the role of informal organizations which promote the Russian language and culture in Spain and participate in the process of generating and implementing the Russian soft power strategy.

Analysis. The implementation of the soft power policy pursued by states is accompanied by the development of its institutional structure, resource and information-image support. The most active institutions in the humanitarian dimension of foreign policy and cultural diplomacy in Western Europe are the Alliance Francis (France), the Intergovernmental Agency of French-speaking countries (France), the British Council (the United Kingdom), the Goethe-Institut (Germany), the Cervantes Institute (Spain), etc. The Federal Agency for the Commonwealth of Independent States, Compatriots Living Abroad and International Humanitarian Cooperation (Rossotrudnichestvo) fulfills this function in Russia, and its strategic direction is determined by the Russian Ministry of Foreign Affairs. This specialized institute coordinates with the foreign diaspora, directs efforts to preserve the language in this environment and spreads the Russian language and culture among foreign citizens. In recent years, the priority area of Rossotrudnichestvo is to find ways to export the cultural product [50, p. 244] as an instrument of soft power.

The need of supporting the positive image of Russia on the global stage was first officially mentioned in the Foreign Policy Concept of the Russian Federation approved by a Presidential Decree in 2000 [22]. The 2013 Foreign Policy
Concept contained the term "soft power" itself. Thus, according to clause 20, "Soft power, a comprehensive toolkit for achieving foreign policy objectives building on the civil society potential, information, cultural and other methods and technologies alternative to traditional diplomacy, is becoming an indispensable component of modern international relations" [23].

The national language and culture play a very important role in presenting the image of a country on the global stage.

The president of Russia focuses on preserving, developing and promoting the Russian language as it plays an important role in strengthening the sovereignty and integrity of Russia, consolidation of the Russian society and inclusion of Russia into the global economic, political, cultural and educational space [47].

Currently, Russian becomes more and more important in the world policy. It serves as the language of cross-national communication and is one of the United Nation languages. According to Ethnologue: Languages of the World reference, in 2017, the Russian language was ranked the $4^{\text {th }}$ after English, Chinese and Spanish: the number of Russian-speaking people in the world exceeded 258 million people [13]. Besides, Russian is the official working language of many international organizations such as the United Nations Educational, Scientific and Cultural Organization (UNESCO), the United Nations (UN), and EuroAsian Economic Community (EurAsEC), etc.

At present, the Russian language plays a leading role in uniting the sociopolitical and cultural space of the Russian world [15, p. 221], which was formed over time as a result of several emigrant waves under the influence of historical changes in the fate of Russia [31, p. 179]. Today, the Russian world, which is the world of a special trans-state and transcontinental culture, is an important strategy of Russia for creating the country image on the global stage [27]. At the same time, it should be admitted that unfortunately, the concept of the Russian world is largely unknown abroad, so a more active promotion of the Russian language and culture on the global stage is important for its popularization [43]. Moreover, in the context of soft power, the Russian world can present a strategy like the post-imperial cultural "world" known as Hispanidad or Francophonie [52]. 
Currently, Russia has a huge cultural and language heritage and it is interested in strengthening and expanding its own positions in the international arena. Hence, Russia faces the task of actively using these resources.

According to V. Tishkov, academic fellow and director of the Institute of Ethnology and Anthropology of the Russian Academy of Sciences, language has always served as a means of political and ideological impact, interstate and intergroup domination and rivalry [51, p. 295].

Presently, to strengthen the authority of Russia on the global stage it is important not only to promote the Russian cultural heritage abroad, but also to preserve and strengthen the Russianspeaking area [29, p. 93]. Therefore, language activity is one of the priority areas of the Russian governmental soft power policy.

According to A. Gromyko, director of Institute of Europe of the Russian Academy of Sciences, the Russian language and culture are the world brands of Russia which millions of people around the world are familiar with or heard of. But these brands should be developed and promoted on the global stage; otherwise they will stop playing any significant role in the country's impact abroad [17, p. 11]. This point of view is very relevant, since in the new geopolitical situation that appeared in the world after 2014 there was a noticeable strengthening of the eastern vector of Russia's foreign policy. This entailed the expansion of opportunities to strengthen and promote the position of the Russian language in the countries of the AsiaPacific region. At the same time, there was a risk of weakening the position of the Russian language in several European countries due to the development of anti-Russian sentiments and unfriendly measures. Under these conditions, the government of the Russian Federation recognized the optimal distribution of program activities for specific countries of their implementation, taking into account the current situation in line with Russia's geostrategic interests, as a measure to minimize these risks.

Spain occupies a special place in the foreign policy concept of modern Russia. Relations between the two countries have a long history with rises and falls during different epochs of its existence [1, p. 5]. A triple anniversary of RussianSpanish relations was celebrated in 2017: 40 years since resuming the diplomatic relations, 350 years since the arrival of the first Russian embassy headed by stolnik Potemkin to Madrid and 500 years since the first official contact between Russia and Spain when Charles V, King of Spain and Holy Roman Emperor, sent a message with an offer to establish diplomatic relations to Vasili III, Grand Prince of Moscow [28]. Besides, it should be mentioned that the leading world paleogenetics have proved that the contemporary Spaniards are descendants of the inhabitants of Black Sea and Caspian steppes, thus, this can also serve as a factor for bonding both nations [26]. Historically, the cultural and humanitarian sphere was a strong point of the bilateral co-operation. Unfortunately, the Russian language in Spain is not so widespread as Spanish in Russia [12, p. 96].

The new impulse for the Russian-Spanish cultural and humanitarian cooperation in the sphere of popularization, support and development of the Russian language was given at the cusp of the new millennium after Putin visited Spain in 2000. After that, a number of agreements were signed, which served as the legal basis for further expansion of the bilateral cooperation, (including: "Program of co-operation between the Kingdom of Spain and the Russian Federation in the sphere of culture and education for 2005-2007" [41], "Declaration of strategic partnership between the Russian Federation and the Kingdom of Spain for 2009" [5]. In particular, the Program provided for mutual assistance in teaching the Russian language in Spain and Spanish in Russia for a deeper knowledge of the languages, literature and culture of the two countries [41].

An important tool of cultural diplomacy was the organization and conduct of cross-years. The Russian-Spanish bilateral year practice was established in 2011 when the first Russia-Spain Cross-Cultural Year was held. The Cross-Year of the Language and Literature of Russia and Spain was held in 2015-2016 and after that in 2016-2017 the Year of Tourism was held. As part of these cross-years, a lot of events were held in various areas of bilateral cooperation, which have arisen new interest in the Russian culture and language. Opening of the Málaga branch of the Russian Museum in 2015 was a milestone event. It is planned to open a Hermitage branch in Barcelona in the nearest future.

In the context of soft power politics, Days of the Russian language and culture are regularly 
held in different cities and regions of Spain. As a result of such events very important acrions took place that affect the process of perception of Russia in Spain, for example, the unveiling of the monuments to A. Pushkin in Granada and Madrid, and the monument to Yu. Gagarin in Alicante.

2019-2020 was declared the RussianSpanish cross-year of science and education. According to the Ambassador of Russia to Spain Yu.P. Korchagin, different projects implemented within the framework of this cross-year, help build confidence between the two countries, as well as intensify various academic, cultural, scientific and humanitarian relations [58, p. 442].

In these conditions, Russia and Spain consider the mutual study of languages and cultures as a basis for further expansion of cooperation in the humanitarian, socio-political and other spheres of society [2, p. 27].

However, as Spain is an attractive resort among Russians, at present there is currently a growing popularity of studying the Russian language and culture in Spain. Thus, Spain is visited by more than 1 million Russian citizens each year [19]. In 2017, compared with 2016, $14 \%$ more Russian tourists arrived: $2016-1.005 .000$ people, $2017-$ 1.151 .000 people, $2018-1.228 .000$ people [48]. There is also a gradual increase in the number of Spanish tourists in Russia. Their number in 2017 amounted to about 120 thousand people [42].

As it is known, football is the most popular kind of sports in Spain. In this regard, an important event to strengthen Russia's image in the world was the 2018 FIFA World Cup. The FIFA World Cup allowed, on the one hand, to attract Spanish tourists to matches in Russia and to show the tourist attractiveness of the Russian Federation as the hostess of the championship, and on the other hand, the interest in the Spanish language in Russia has been reawakened.

For its part, the Russian Federation in recent years have been actively implementing its cultural diplomacy, including in the field of language policy aimed at spreading the Russian language and raising its status abroad. To achieve this goal, the Russian Language Federal Targeted Program was developed [34, p. 72]. The Program refers to the creation of a "competitive international instrument of communication in the field of science and education," about "the development of new bilateral and multilateral forms of cooperation with foreign states that contribute to the spread of the Russian language in the world and at the same time do not impede the use and popularization of other languages" [21, p. 24].

Currently, the fourth program for the period 2016-2020 is being implemented. It is aimed for "developing the overall application and promotion of Russian as a fundamental of civil self-identity, cultural and educational unity of multinational Russia, efficient international dialogue" [14].

The Ministry for Foreign Affairs of the Russian Federation also makes its contribution into the preservation and consolidation of the Russian position abroad. This allows increasing the number of schools and classrooms for learning Russian, retraining teachers from Russian-speaking schools and organizing study trips to Russia.

The Federal Agency for the Commonwealth of Independent States Affairs, Compatriots Living Abroad, and International Humanitarian Cooperation (Rossotrudnichestvo) is one of the main structures in the sphere of promotion and preservation of the Russian language and culture abroad. The agency is the successor of the Russian Center for International Scientific and Cultural Cooperation (formerly - the Union of Soviet Societies for Friendship and Cultural Relations with Foreign Countries (VOKS) established in 1925) [20]. The VOKS began its activity in Spain only in 1986 [16]. Within this organization, the Spain-USSR Association acted, which largely contributed to the expansion of the cultural presence of the USSR in Spain and Spain in the USSR and laid the foundations for studying the Russian language in Spain outside state educational institutions.

A representation of Rossotrudnichestvo in Spain - The Russian Science and Culture Center was opened in 2011 in Madrid. Along with the Ministry of Foreign Affairs of Russia and Rossotrudnichestvo, Russia forms its own public infrastructure, focused on the long-term work in the field of humanitarian and cultural diplomacy. This is evidenced by the development process of foundations and non-governmental organizations of foreign policy: the Institute for Democracy and Cooperation, the Russkiy Mir Foundation, the Russian Language Center, etc.

The Russkiy Mir Foundation plays a special role in the diplomacy of soft power and the expansion of cultural and humanitarian 
cooperation between Russia and Spain. According to the Decree of June 21, 2007 of the president of Russia on establishing the Russkiy Mir Foundation, this is done "for promoting Russian as a national asset of Russia and an important part of Russian and world culture so as for supporting programs for learning Russian abroad" [54]. The Russkiy Mir Foundation activities in preserving the Russian language also involve federal legislative and executive authorities, Russian regions, mass media and educational institutions of all levels.

The Russian center in Valencia, Russian center at the University of Granada and Russian center of the Russia House in Barcelona have been opened with the assistance of the Russkiy mir Foundation [57]. The Russkiy Mir Cabinet program is one of the main of the Russkiy mir Foundation programs. This project is targeted on supporting the activity of non-profitable organizations for the promotion and popularization of the Russian language, literature and culture [38]. The first Russkiy Mir Cabinet was opened in Catalonia in 2011 based on the Russian Center of Science and Culture named after A. Pushkin. Besides, a similar Russkiy Mir Cabinet operates in Madrid. The Russian side provides the participants of the program with academic, scientific and fiction literature; visual aids; multimedia, photo and video materials; technical means of reproduction; access to network information resources in Russian, etc. [4].

Currently, the Pushkin Russian Language Institute in Barcelona established in 1992 is one of the largest Russian educational and cultural centers in Spain. The Centre of the Russian language and culture in the University of Cádiz and Pushkin Russian Institute in Madrid have been opened at its premises in 2016 and 2018 correspondingly. Through various cultural and educational events, the Pushkin Russian Language and Culture Institute in Barcelona have been popularizing the Russian language and culture in Spain. In addition to the main Russian language course, the Institute conducts various special courses, for example, business courses, tourism courses, Russian language courses for parents who want to adopt a child in Russia, etc. The consulate-general of Russia in Barcelona and Embassy of Russia in Spain help the Institute in its activity [37].
The Alexander Pushkin Foundation has been opened in the rise of the $90 \mathrm{~s}$ for the popularization of the Russian language and culture in Spain with the active participation of Valentina Tereshkova - the first spacewoman. This Foundation is the main center for promoting the Russian language and popularizing Russian culture. From 2000 to 2014, an average of 220 students per year studied the Russian language at the Alexander Pushkin Foundation. In 2015, the Foundation for the first time opened the Russian language courses also for children - from 4 to 6 years old [3, p. 21].

Educational organizations are an important tool of soft power policy of the state [32, p. 4820]. Presently, more Spanish students learn Russian as a second language.

The University of Granada is the oldest place for studying Russian in Spain; a Russian studies center has been actively operating there for 60 years already. The university has been successfully developing relations with foreign educational institutions and has entered into several bilateral agreements with leading Russian higher educational institutions (Saint Petersburg University, Moscow State Linguistic University, Kazan Federal University, etc.) [56].

The Russkiy Mir Foundation together with the University of Granada publishes "Cuadernos de rusística española", which is the only publication on Russian studies in Spain and in the Spanishspeaking world. This publication issues studies on current issues of linguistics and literary criticism, theory and practice of teaching the Russian language [18, p. 7].

The Universities of Granada, Madrid, Barcelona, Valladolid, Santiago de Compostela, Alicante and other cities have departments with the "Slavic philology" specialization with advanced learning of Russian for Spanish students [10]. In 2015, approximately 7000 Spanish students learned Russian [39].

The interest to learning Russian in Spanish schools has also increased. According to the report "Russian in the world" of the Ministry for Foreign Affairs of Russia of 2001, 3000 persons in Spain learned Russian (approximately 700 persons at the universities and more than 1,600 persons at public foreign languages schools, the rest at private educational schools and courses) [6]. In 2014-2015 this figure has been exceeded significantly; it was 
established that 3,500 schoolchildren learned Russian [8].

Unfortunately, at present, the Russian language is taught only in 16 schools among the 300 official schools in Spain. However, due to the low tuition fees, there are many students who want to learn Russian in these schools [3, p. 19].

Great efforts in supporting the Russian language and culture in Spain are made by the International Association of Teachers of Russian Language and Literature (MAPRYAL) [17, p. 15]. The congresses of MAPRYAL, which take place every four years in different countries of the world, are very important for the development of the world linguistics and Russian studies.

In 2015, in the Cross-Year of Russian and Spanish Languages and Literature, which took place in Russia and Spain, the $8^{\text {th }}$ MAPRYAL Congress was held at the University of Granada [36]. The opening of the monument to A. Pushkin on the territory of the oldest University of Granada was timed to coincide with this event.

Thus, the educational sphere is one of the strongest points of Russian-Spanish relations. In recent years, especially after Russia's transition to the Bologna Process, Russian universities focus on bilateral cooperation between higher educational institutions in the sphere of developing joint educational programs for dual degrees, student and academic mobility as well as mutual recognition of degrees [33, p. 194].

Such Russian higher educational institutions as Moscow State University, St Petersburg University, Peoples' Friendship University of Russia, Higher School of Economics National Research University, Voronezh State University, Pyatigorsk State University, Kazan Federal University and Moscow State Linguistic University perform active international activities and successfully co-operate with many Spanish universities on the basis of corresponding agreements. Recently the overall scale of implementing bilateral educational programs has been extended significantly [59, p. 3698]. The number of Spanish students studying at Russian universities in 2017/2018 amounted to 311 people (303 of them are full-time students), 3 Spanish students studied at secondary vocational schools and a little over 20 children from families of Spanish citizens studied in secondary schools. At the same time, this indicator of the number of full-time students in Russian universities in the academic years 2016/2017 and 2017/2018 was 268 and 292 students, respectively [9].

One of the important results of the cooperation between Spain and Russia in the field of education is the agreement of the two countries on the mutual recognition of education, qualifications and academic degrees. Secondary and higher education received in Russia and confirmed by diplomas and education of the appropriate level received in Spain will be recognized as comparable. In addition, the agreement is equal to the degree of candidate of sciences obtained in Russia and the degree of doctor (Título de Doctor) obtained in Spain. Signing of the similar document was an important step in the development of Russian-Spanish relations, which will open new opportunities for further development of academic mobility and the attraction of highly qualified personnel.

It should be mentioned that the diaspora resources play an important role in the soft power policy of any state. In the post-Soviet period, there was an understanding that "Russia and the foreign Russian world are part of one ethno-cultural space" [30]. The Russian government today considers compatriots as the basis of Russian influence abroad. The Ministry of Foreign Affairs of the Russian Federation and Rossotrudnichestvo have established the Fund for the Support and Protection of the Rights of Compatriots Living Abroad. The Fund performs such important tasks such as protecting compatriots from any forms of discrimination, enforcing their legal rights and freedom, providing an opportunity to study their native language, preserving cultural and spiritual traditions [60].

Currently, many Russian speakers live in Spain. According to the statistics of 2017, about 73 thousand citizens of the Russian Federation lived in Spain. And this indicator is growing steadily [49]. According to the Spanish National Statistics Institute as of January 1, 2019, there were 4.9\% more residents registered as immigrants from Russia [40] compared with the same indicator in 2018 (73,930 people) [11]. According to the results of 2019, the number of residents-immigrants from Russia has already reached 77,379 people [48].

Presently, most Russian compatriots who live in Spain have integrated into the business, cultural and scientific life of Spanish society and at the 
same time created institutions to preserve their national identity and native language.

Such Russian-speaking organizations as Fyodor Dostoyevsky Association of Russian culture, Russian SevilleAssociation of compatriots, Creixer Junts Association dealing with intercountry adoption, Centre of Russian language and culture association, Russian Word Association of teachers of Spain, Olimpiya Association of parents of bilingual children have been established in Madrid, Barcelona, Palma de Mallorca, Zaragoza, Pamplona and many other cities.

By creating associations, cultural centers and schools, Russian compatriots strengthen the position of Russian culture and expand cooperation between various educational institutions of Russia and Spain and promote domestic educational services. In turn, this favorably influences the consolidation of bilateral relations and creates a positive image of Russia in Spain [12, p. 97].

Different theme holidays, concerts, festivals, exhibitions and other events devoted to anniversaries of outstanding Russian cultural figures and important dates in the history of Russia are organized on a regular basis for developing educational and cultural relations with compatriots, supporting and preserving Russian spiritual, cultural and language environment so as to strengthen the positive image of Russia in Spain [7].

In this area, annual campaign devoted to the Victory Day - Memorial March, which was held in Spain in 2016 for the first time - is very important. A good tradition introducing the Spaniards to Russian history is holding patriotic and memorial festivals "Victory" and "I Remember! I'm proud!'.

Besides, the activity of language courses, Saturday schools, trainings and education centers for bilinguals is worth mentioning. Both adults and children from bilingual families study here. These centers were opened upon the initiative of active Russian compatriots in Spain. There are a lot of such schools in Spain: "Azbuka", "Slovo", "Raduga" schools for children of Russian compatriots, "Parus" summer school-camp, etc. [44].

According to O. Lavrova, President of "Parus" Centre of Russian language and culture in Alicante, teaching the Russian language and literature to children will make them people of the new generation who combine and develop the best traditions of two cultures [45].
Russian-language media are of great importance for the Russian diaspora both to preserve their cultural and linguistic origin, and to inform compatriots and tourists. There is a large selection of Russian-language newspapers and magazines in Spain: "Russian Inn", "MK News of Spain", "ImpulsPlus", "SUR in Russian", "IMPULS", "LINDA", etc. There is also Russian-Language radio and TV channels: "Matrioshka FM", "RusRadio Marbella", "Smile FM", "Radio Kartina", "Russian Radio Mallorca", "Spain TV". The most popular Russian-language information websites in Spain are "AvtoSputnik Marbella", "Our Spain", "MADRIDRU.ES", "Spain in Russian", "Noticia.ru", etc. [55].

Speaking about the role of mass media, primarily the Internet, television and radio broadcasting, in the modern world, A. Sukharev rightly notes the following: "In the field of public diplomacy, the ultimate effectiveness of this work is determined not so much by a well-balanced broadcast format and its informational content, as by the creating a communications trust environment" [50, p. 307].

Results. The study shows that in the context of modern globalization processes, the success of a state in the international arena largely depends on its ability to promote its language and culture and increase its status abroad. The example of Russia shows that thanks to the promotion of the Russian language and culture in the EU countries and, in particular, in Spain, it provided direct access to the culture of the Russian peoples, and there are wide opportunities for intercultural interaction between Russia and Spain.

At the same time, today, in the conditions of confrontation with the West, Spain is one of the few countries of the European Union whose position towards Russia remains sympathetically neutral. In many ways, Madrid's similar attitude to Moscow is due to the long-standing historical and cultural relations between the two countries, which were not interrupted even in the most difficult historical periods.

In turn, Spain remains a partner for Russia, with which Moscow seeks to intensify mutually beneficial bilateral relations, considering them as an important resource for promoting its own national interests.

It can be stated that in recent years Russia has managed to maintain, and in some positions 
expand its presence in Spain in the humanitarian and information spaces. It created its own institutional system in Spain, which includes state and public structures, professional organizations, and cultural centers. Rossotrudnichestvo takes a special role in the system of Russian departments operating in the field of cultural and humanitarian diplomacy. Thanks to Rossotrudnichestvo, a model for teaching the Russian language with the participation of specialists, and a successful system for testing Russian as a foreign language was created in Spain.

In turn, this contributes to the growth of Russian credibility in the Spanish market of educational services, as it is evidenced by the many years of experience in the development of double diploma programs and double postgraduate studies, as well as the agreement concluded in 2019 on the mutual recognition of education, qualifications and academic degrees.

However, based on the current situation in the world, it becomes clear that more effective measures and more powerful economic resources are required to expand the Russian humanitarian presence abroad. Moreover, it is obvious that it is the policy of promoting Russian that serves as the most important instrument of cultural diplomacy in Russia, a manifestation of the resource of its soft power in the context of globalization. With regard to Spain, the soft power policy contributes to the development of a dialogue between the world of Spain and the Russian world, strengthening mutual understanding between the peoples of the two countries, which is important for creating a positive image of Russia in Spain and in the international arena as a whole.

\section{NOTES}

${ }^{1}$ The publication has been prepared with the partial support of the "RUDN University Program 5-100".

\section{REFERENCES}

1. Alekseev M.P. Russkaya kultura i romanskiy mir [Russian Culture and Romanesque World]. Leningrad, Nauka, Leningr. otd-nie, 1985. 542 p.

2. Andreeva T.L., Kern K.N. Lingvisticheskiy aspekt kak faktor vneshney politiki KNR v XXI v. [Linguistic Aspect as a Factor of the Foreign Policy of the People's Republic of China in the XXI Century].
Vestnik Tomskogo gosudarstvennogo universiteta [Bulletin of Tomsk State University], 2017, no. 417, pp. 25-29.

3. Chernosvitov A.A. Kto i kak uchit russkiy yazyk v Ispanii? [Who and How Teaches Russian in Spain?]. Russkiy yazyk za rubezhom (spetsialnyy vypusk) [Russian Language Abroad (Special Issue)], 2017, pp. 17-25. URL: https://journal-rla. pushkininstitute.ru/files/Испания.pdf (accessed 23 June 2019).

4. Chto takoe KABINET? (What Is the Cabinet?). URL: https://russkiymir.ru/rucenter/ cabinet.php (accessed 27 May 2019).

5. Deklaratsiya o strategicheskom partnerstve mezhdu Rossiyskoy Federatsiey i Korolevstvom Ispaniya $2009 \mathrm{~g}$. [Declaration of Strategic Alliance Between Spain and the Russian Federation 2009]. URL: http://kremlin.ru/supplement/163 (accessed 18 May 2019).

6. Doklad MID Rossii. Russkiy yazyk v mire [Report of the Russian Foreign Ministry. Russian Language in the World]. URL: https://www.gumer.info/ bibliotek_Buks/Culture/Russian/_Index.php (accessed 5 June 2019).

7. Doklad o rezultatakh deyatelnosti Rossotrudnichestva po realizatsii vozlozhennykh na nego polnomochiy za 2017 god [Report on the Results of the Activities of Rossotrudnichestvo in 2016]. URL: http://rs.gov.ru/ru/pages/389 (accessed 21 May 2019).

8. Domingo I. Dónde estudiar ruso en España. URL: https://www.rusalia.com/estudiar-ruso-espana (accessed 13 June 2019).

9. Eksport rossiyskikh obrazovatelnykh uslug: Statisticheskiy sbornik. Vypusk 9 [Export of Russian Educational Services. Statistical Compilation. Issue 9]. Moscow, Tsentr sotsiologicheskikh issledovaniy, 2019. $536 \mathrm{p}$.

10. El duro camino de la lengua rusa en España. URL: https://es.rbth.com/internacional/2013/04/11/ el_duro_camino_de_la_lengua_rusa_en_espana_26747 (accessed 10 May 2019).

11. El Instituto Nacional de Estadística. URL: https://www.ine.es/welcome.shtml (accessed 22 June 2019).

12. Ershova V.F., Gadzhieva Kh.D. Russkiy mir v Ispanii i kulturnyy dialog (1991-2015 gg.) [Russian Community in Spain and Global Cultural Dialogue (1991-2015)]. Vestnik Rossiyskogo universiteta druzhby narodov. Seriya: Istoriya Rossii [RUDN Journal of Russian History], 2018, vol. 17, no. 1, pp. 92108. DOI: 10.22363/2312-8674-2018-17-1-92-108.

13. Ethnologue: Languages of the World. URL: https://www.ethnologue.com/language/rus (accessed 18 May 2019).

14. Federalnaya tselevaya programma «Russkiy yazyk» na 2016-2020 gody ["The Russian Language" 
Federal Targeted Programme for 2016-2020]. URL: http://static.government.ru/media/files/UdArRuNmg2 Hdm3MwRUwmdE9N3ohepzpQ.pdf(accessed 3 June 2019).

15. Gorshkova M.K., Andreeva A.L. Rossiyskoe obshchestvo i vyzovy vremeni. Kniga pervaya [Russian Society and the Challenges of Time. Book One]. Moscow, Ves Mir Publ., 2015. 336 p.

16. Gosudarstvennyy arkhiv RF (GA RF) [State Archive of the Russian Federation], F. 9576, Op. 20, D. 1066, L. 6-7.

17. Gromyko Al.A. Russkiy yazyk i kultura v politike «myagkoi sily» Rossii [Russian Language and Culture in the Policy of "Soft Power" of Russia]. Bolshaya Evropa $v$ globalnom mire: novye vyzovynovye resheniya [Wider Europe in the Global World: New Challenges - New Solutions], 2013, pp. 9-16.

18. Gusman Tirado R. O russkom yazyke v Ispanii i v Granadskom universitete [About the Russian Language in Spain and at the University of Granada]. Russkiy yazyk za rubezhom (spetsialnyy vypusk) [Russian Language Abroad (Special Issue)], 2017, pp. 4-9. URL: https://journal-rla.pushkininstitute.ru/ files/Испания.pdf(accessed 23 June 2019).

19. Intervyu Ministra inostrannykh del Rossii S.V. Lavrova ispanskoy gazete "El Pais», opublikovannoe 5 noyabrya 2018 goda [Interview with Russian Minister of Foreign Affairs Sergey Lavrov to El Pais Spanish Newspaper Published on November 5, 2018]. URL: https://spain.mid.ru/web/spain_ru/-/ interv-u-ministra-inostrannyh-del-rossii-s-v-lavrovaispanskoj-gazete-el-pais-opublikovannoe-5-noabra2018-goda (accessed 10 June 2019).

20. Istoriya Rossotrudnichestva [History of Rossotrudnichestvo]. URL: http://rs.gov.ru/ru/pages/ 122 (accessed 18 June 2019).

21. Kontseptsiya gosudarstvennoy podderzhki $i$ prodvizheniya russkogo yazyka za rubezhom [Concept for State Support and Promotion of the Russian Language Abroad]. URL: http://www. consultant.ru/document/cons_doc_LAW_188569 (accessed 21 May 2019).

22. Kontseptsiya vneshney politiki Rossiyskoy Federatsii, utverzhdennaya ot 28 iyunya $2000 \mathrm{~g}$. [Foreign Policy Concept of the Russian Federation Approved on June 28, 2000]. URL: http://docs.cntd.ru/ document/901764263 (accessed 15 May 2019).

23. Kontseptsiya vneshney politiki Rossiyskoy Federatsii ot 12 fevralya 2013 g. [Foreign Policy Concept of the Russian Federation Dated February 12, 2013]. URL: http://archive.mid.ru//BRP_4.NSF/0/ 6D8424DDEDEDBF7DA644257B160051BF7F (accessed 15 May 2019).

24. Koroleva A.A. Strategiya «myagkoy sily» v formirovanii vneshnego imidzha Rossii i Ispanii [The Strategy of "Soft Power" in the Formation of the
External Image of Russia and Spain]. Pravo $i$ upravlenie. XXI vek [Law and Management. XXI Cent.], 2015, no. 1,pp. 97-103.

25. Krasina O.V. "Myagkaya sila» kak teoreticheskaya konstruktsiya $i$ vlastnaya tekhnologiya sovremennoy mirovoy politiki. Sovrem. gumanitar. akad. ["Soft Power" as a Theoretical Design and a Powerful Technology of the Modern World Politics. Modern Humanitarian Academy]. Moscow, Izd-vo Sovremennogo gumanitarnogo universiteta, 2011. $139 \mathrm{p}$.

26. Lomeyko A. Uchenye nashli skhodstvo mezhdu DNK ispantsev i rossiyan [Scientists Have Found Similarities Between DNA of Spaniards and Russians]. URL: https://360tv.ru/news/nauka/ uchenye-nashli-shodstvo-mezhdu-dnk-ispantsev-irossijan/ (accessed 21 May 2019).

27. "Mir Russkogo mira». Stenogramma podiumnoy diskussii ["World of the Russian World." Transcript of the Podium Discussion]. URL: https:// www.russkiymir.ru/analytics/tables/news/67916/ (accessed 16 May 2019).

28. Moiseev A. Posol Rossii v Ispanii: Vysokiy interes nashikh narodov $k$ kulture drug druga - eto aksioma [Russian Ambassador to Spain: The High Interest of Our Peoples in Each Other's Culture Is an Axiom]. URL: http://pravfond.ru/?module=articles\& action=view\&id=199 (accessed 16 May 2019).

29. Molodov O.B. Russkiy yazyk kak instrument ispolzovaniya «myagkoy sily» v stranakh tsentralnoy Azii [Russian Language as the Instrument of "Soft Power" in the Countries of Central Asia]. Diskurs-Pi [Discourse-P], 2017, no. 26, pp. 93-96.

30. Moseykina M.N. Diasporalnaya diplomatiya Rossii v stranakh Latinskoy Ameriki: istoricheskiy opyt i perspektivy [Diasporal Diplomacy of Russia in Latin America: Historical Experience and Prospects]. Vestnik Rossiyskogo universiteta druzhby narodov. Seriya: Mezhdunarodnye otnosheniya [Vestnik RUDN. International Relations], 2015, no. 4, pp. 66-73.

31. Moseykina M. N. U istokov formirovaniya Russkogo mira. XIX-nachalo XX veka [At the Origins of the Formation of the Russian World. $19^{\text {th }}-$ Early $20^{\text {th }}$ Century)]. Moscow, AIRO-XXI Publ., Saint Petersburg, Aleteyya Publ., 2014. 392 p.

32. Moseikina M., Kuznetsova V., KriazhevaKartseva E., Bosrisov V. The Problems of the International Cooperation Development in the Field of Education Between Russia and Spain (On the Example of Implementation of the Double Diplomas Program for the PFUR and the UIB). INTED2018 Proceedings, 2018, pp. 4820-4825. DOI: 10.21125/inted.2018.0942.

33. Moseykin Y.N. Las tendencias mundiales y la reforma de la educación superior en Rusia. España y Rusia frente a los nuevos desafíos globales. Moscú, ILA RAN, 2016, pp. 192-198. 
34. Niyazova G.A. Lingvisticheskoe izmerenie politiki Rossii $i$ Velikobritanii v Azerbaydzhane $v$ kontekste globalnykh protsessov: dis. ... kand. polit. nauk [Linguistic Dimension of the Policy of Russia and Great Britain in Azerbaijan in the Context of Global Processes. Cand. polit. sci. diss.]. Saint Petersburg, 2014. 181 p.

35. Nye J. Soft Power: The Means to Success in World Politics. New York, Public Affairs, 2005. 191 p.

36. O XIII Kongresse Mezhdunarodnoy assotsiatsii prepodavateley russkogo yazyka $i$ literatury (MAPRYaL) [About the $13^{\text {th }}$ Congress of the International Association of Teachers of Russian Language and Literature (MAPRYAL)]. URL: http:// www.mid.ru/web/guest/maps/es/-/asset_publisher/ qqAftQ2HgNEM/content/id/1802728 (accessed 24 May 2019).

37. Ofitsialnyy sayt Instituta russkogo yazyka im. A.S. Pushkina [Official Website of the Russian Language Institute Named After A. Pushkin]. URL: http://www.centroruso.es/ru (accessed 15 May 2019).

38. Ofitsialnyy sayt Rossiyskogo tsentra nauki $i$ kultury v Madride [Official Website of the Russian Centre for Science and Culture in Madrid]. URL: http:// esp.rs.gov.ru/ru (accessed 14 May 2019).

39. Perekrestnyy god russkogo $i$ ispanskogo yazykov okhvatit sto meropriyatiy [The Russia-Spain Cross-Cultural Year Will Cover One Hundred Events]. URL: https://ria.ru/20150526/1066462002.html (accessed 14 June 2019).

40. Pokupateli propisalis v Ispanii. Oni vybirayut nedvizhimost dlya immigratsii [Buyers Apply for Residence in Spain. They Choose Property for Immigration]. URL: https://www.kommersant.ru/ doc/4047024 (accessed 12 June 2019).

41. Programma sotrudnichestva mezhdu Rossiyskoy Federatsiey $i$ Korolevstvom Ispaniya $v$ oblasti kultury i obrazovaniya na 2005-2007 gody [Program of Cooperation of the Russian Federation and the Kingdom of Spain in the Field of Culture and Education for 2005-2007]. URL: http://docs.cntd.ru/ document/901764263 (accessed 23 May 2019).

42. Rusia, el mercado que más crece en España. URL: https://www.hosteltur.com/127099_rusiamercado-crece-espana.html (accessed 6 June 2019).

43. Russkiy mir-obshchnost vsekh, kto verit $v$ Rossiyu [Russian World - Community of Those Who Believe in Russia]. URL: http://pyмир.pф/publications/ 216304 (accessed 16 May 2019).

44. Russkie shkoly v Ispanii [Russian Schools in Spain]. URL: https://espanarusa.com/ru/pedia/article/ 551522 (accessed 17 May 2019).

45. Russkie shkoly v Ispanii: obyedinyaya detey, my obyedinyaem i ikh roditeley [Russian Schools in Spain: Uniting Children, We Unite Their Parents]. URL: https://www.russkiymir.ru/publications/233383 (accessed 31 May 2019).
46. Smirnov N.A. Rol publichnoy diplomatii v sovremennykh politicheskikh protsessakh: dis. ... kand. polit. nauk [Role of Public Diplomacy in Modern Political Processes. Cand. polit. sci. diss.]. Moscow, 2017. 167 p.

47. Sovmestnoe zasedanie Soveta po mezhnatsionalnym otnosheniyam $i$ Soveta po russkomu yazyku [Joint Meeting of the Council on Interethnic Relations and the Council on the Russian Language]. URL: http://kremlin.ru/events/president/ news/49491 (accessed 18 May 2019).

48. Statista. URL: https://es.statista.com (accessed 22 December 2019).

49. Sube el número de emigrantes de Rusia. URL: https://datosmacro.expansion.com/demografia/ migracion/emigracion/rusia?anio $=2017 \#$ geo $($ accessed 30 May 2019).

50. Sukharev A.I. Transgumanitarnoe izmerenie politiki: Opyt issledovaniya institutsionalizatsii NPO-seti v mezhdunarodnykh otnosheniyakh [TransHumanitarian Dimension of Foreign Policy: The Experience of Institutionalizing the NonGovernmental Environment in International Relations]. Moscow, Kniga i biznes Publ., 2009. 442 p.

51. Tishkov V.A. Yazyki natsii [The Languages of Nation]. Vestnik Rossiyskoy akademii nauk [Herald of the Russian Academy of Sciences], 2016, vol. 86, no. 4, pp. 291-303.

52. Tishkov V.A. Russkiy mir: smysl i strategii [Russian World: Meaning and Strategy]. Strategii Rossii [Russian Strategies], 2007, no. 7. URL: http:// sr.fondedin.ru/new/fullnews_arch_to.php?subaction $=$ showfull\&id $=1185274651 \&$ archive $=1185275035 \&$ start_from $=\& u c a t=14 \&$ (accessed 9 June 2019).

53. Tsvyk G.I. Prodvizhenie russkogo yazyka v KNR kak instrument kulturnoy diplomatii Rossiyskoy Federatsii v 2001-2017 gg.: dis. ... kand. ist. nauk [Promotion of the Russian Language in the People's Republic of China as an Instrument of Cultural Diplomacy of the Russian Federation in 2001-2017. Cand. hist. sci. diss.]. Moscow, 2018. 157 p.

54. Ukaz Prezidenta Rossiyskoy Federatsii «O sozdanii fonda «Russkiy mir» [Decree of the President of the Russian Federation on the Establishment of the Russkiy Mir Foundation]. URL: https://rg.ru/2007/06/23/ fond-dok.html (accessed 7 May 2019).

55. V Ispanii nachal rabotu novyy russkoispanskiy internet-portal [A New Russian-Spanish Internet Portal Has Been Launched in Spain]. URL: http://pravfond.ru/?module=news\&action=view\&id= 5836 (accessed 27 May 2019).

56. V universitete Granady otkryt «Russkiy tsentr» 22.05.2015 [The Russian Center Opens at the University of Granada]. URL: http://www.mid.ru/web/ guest/maps/es/-/asset_publisher/qqAftQ2HgNEM/ content/id/1511566 (accessed 25 May 2019). 
V.V. Kuznetsova. Promoting the Russian Language and Culture in Spain as a Soft Power Tool of the Russian Federation

57. Vuniversitete Valensii otkryvaetsya Russkiy tsentr [The Russian Center Opens at the University of Valencia]. URL: https://gorchakovfund.ru/news/view/ v-universitete-valensiya-otkryvaetsya-russkiy-tsentr (accessed 26 May 2019).

58. Vepretskaya T.Yu. Mastera kultury: Khose Karreras i Plasido Domingo v Rossii [Masters of Culture: Placido Domingo and Jose Carreras in Russia]. Ispaniya i Rossiya: diplomatiya $i$ dialog kultur. Tri stoletiya otnosheniy [Spain and Russia: Diplomacy and Dialogue of Cultures. Three Centuries of Relationships]. Moscow, Indrik Publ., 2018, pp. 440-444.

59. Veselova I. International Cooperation in the Area of Training Highly Qualified Academic Specialists
(The Case of Double PhD Program Between the PFUR and the UIB). INTED 2019 Proceedings: $13^{\text {th }}$ International Technology, Education and Development Conference. Valencia, 2019. Valencia, 2019, pp. 3696-3699. DOI: 10.21125/inted.2019. 0944- 3699.

60. Vsemirnyi kongress sootechestvennikov [World Congress of Compatriots]. Ofitsialnyy sayt Posolstva Rossiyskoy Federatsii v Korolevstve Ispaniya [Official Website of the Embassy of the Russian Federation in the Kingdom of Spain]. URL: https://spain.mid.ru/web/spain_ru/-/vsemirnyjkongress-sootecestvennikov (accessed 29 May 2019).

\section{Information About the Author}

Viktoriia V. Kuznetsova, Postgraduate Student, Department of Russian History (Dual Degree Ph.D. Programme Between RUDN University and the University of the Balearic Islands, Spain), Peoples' Friendship University of Russia, Miklukho-Maklay St., 6, 117198 Moscow, Russian Federation, kuznetsova_vv@pfur.ru,https://orcid.org/0000-0003-4545-1676

\section{Информация об авторе}

Виктория Владимировна Кузнецова, аспирант кафедры истории России (программа двойной аспирантуры между РУДН и Университетом Балеарских островов, Испания), Российский университет дружбы народов, ул. Миклухо-Маклая, 6, 117198 г. Москва, Российская Федерация, kuznetsova_vv@pfur.ru, https://orcid.org/0000-0003-4545-1676 